Miroslav Kohan - Miroslava Spronglova - Nadezda Visnovcova - Jakub Misek - Gabriela Spanikova Viera Jakusova - Jan Jakus

\title{
MONITORING OF DATA TRANSMISSION AND CHANGES IN VALUES OF ELECTROMAGNETIC FIELD IN LIVING ENVIRONMENT
}

A crucial aspect concerning the intelligent transport systems is data transmission between vehicle and central control and information systems. Transportation needs a reliable system of data transfer based on GSM or WiFi networks. However, these networks employ a wide range of different frequencies which can be harmful to the health of drivers. The detrimental effect of electromagnetic radiation can negatively affect the process of transportation. This study determines the intensity of electric field levels (E) of the radiofrequency electromagnetic field (RF EMF) during the data transmission through the 3G, 4 G and local WiFi networks, comparing them with the limit values. Conclusions: Our results showed a significantly higher level of the E-field intensity during $4 G$ transmission in all places. The limit values were not exceeded. The lowest E-field values were found in local WiFi network.

Keywords: intelligent transport systems, data transfer, exposure to electromagnetic field, electric intensity, mobile phone, transmission networks

\section{Introduction}

Intelligent transportation needs reliable data transfer between vehicle and control headquarters. Data transfer is based on GSM or WiFi networks. However, these communication networks employ a variety of different frequencies which can have an adverse effect on biological systems including humans. The detrimental effect of electromagnetic radiation can negatively affect driver and persons inside the vehicle, and thus may result in serious problems of transporation.

The history of wireless communication started with the $1^{\text {st }}$ generation $(1 \mathrm{G})$ of the mobile network system. The principle was based on analogue transmission of information. $1 \mathrm{G}$ network had used frequencies of $450 \mathrm{MHz}$ and $900 \mathrm{MHz}$. The successor of $1 \mathrm{G}$ network, also called the Global System for Mobile Communication (GSM), was the $2^{\text {nd }}$ generation $(2 \mathrm{G})$ mobile system. The system had used a cellular principle for signal transmission, which divided the geographic territory into the same large parts (cells). Another system was the $3^{\text {rd }}$ generation (3G) mobile network also called Universal Mobile Telecommunication System (UMTS). The $3 \mathrm{G}$ system has enhanced the data transmission. The UMTS system used a frequency range of $2100 \mathrm{MHz}$. The $4^{\text {th }}$ generation $(4 \mathrm{G})$ was designed for broadband internet access, in the Europe known as the Long Term Evolution system (LTE). It operated at 800, 900, 1800 and 2600 MHz. However, Wireless Local Area Network (WLAN, known as WiFi) operating at $2400 \mathrm{MHz}$ is also very common for data transfer and local internet coverage. It allows users to have a wireless connection within the local area (among buildings, business center, etc.) [1-4].

During the last 20 years the exposure by mobile phones and WiFi routers has rapidly increased. People are exposed to EMF mainly by microwave operating devices and other electronic devices that emit the pulse modulated, high or low frequency EMF [5-6], what seems to be similar problem both at home (a living environment) and work (a working environment). Hence, the exposure of humans to radiofrequency (RF) EMF has always been one of the major topics at the Meetings of the World Health Organization (WHO) [7] and the International Commission on Non-Ionizing Radiation Protection (ICNIRP) [8]. Over the past two decades, worldwide sale of mobile phones has extremely raised up reaching now more than 7.3 billion. In many countries (such as Belgium, Great Britain, Russia, Japan etc.) the number of mobile phones is even higher than the total number of population [9-10]. Thus, the potential detrimental effects of RF EMF are in the interest of both the professionals and also general public. There are many studies referring to the adverse effects of the RF EMF generated by mobile phones on human health [11-16]. WHO has stated that the exposure to RF fields transmitted by mobile phones seems to be now generally higher than from BTSs [17]. Also "urbanicity" seems to be an important determinant of total exposure. Thus, people living in the urban environments have higher RF EMF exposure comparing to those living in the rural environment [18].

\footnotetext{
Miroslav Kohan ${ }^{1 *}$, Miroslava Spronglova ${ }^{2}$, Nadezda Visnovcova ${ }^{1}$, Jakub Misek ${ }^{1}$, Gabriela Spanikova ${ }^{3}$, Viera Jakusova ${ }^{4}$, Jan Jakus ${ }^{1}$

${ }^{1}$ Department of Medical Biophysics, Jessenius Faculty of Medicine in Martin, Comenius University in Bratislava, Slovakia

${ }^{2}$ Department of Biomedical Engineering, Faculty of Electrical Engineering, University of Zilina, Slovakia

${ }^{3}$ Clinic of Pediatric Surgery, Jessenius Faculty of Medicine in Martin, Comenius University in Bratislava, Slovakia

${ }^{4}$ Department of Public Health, Jessenius Faculty of Medicine in Martin, Comenius University in Bratislava, Slovakia

*E-mail of corresponding author: miroslav.kohan@gmail.com
} 

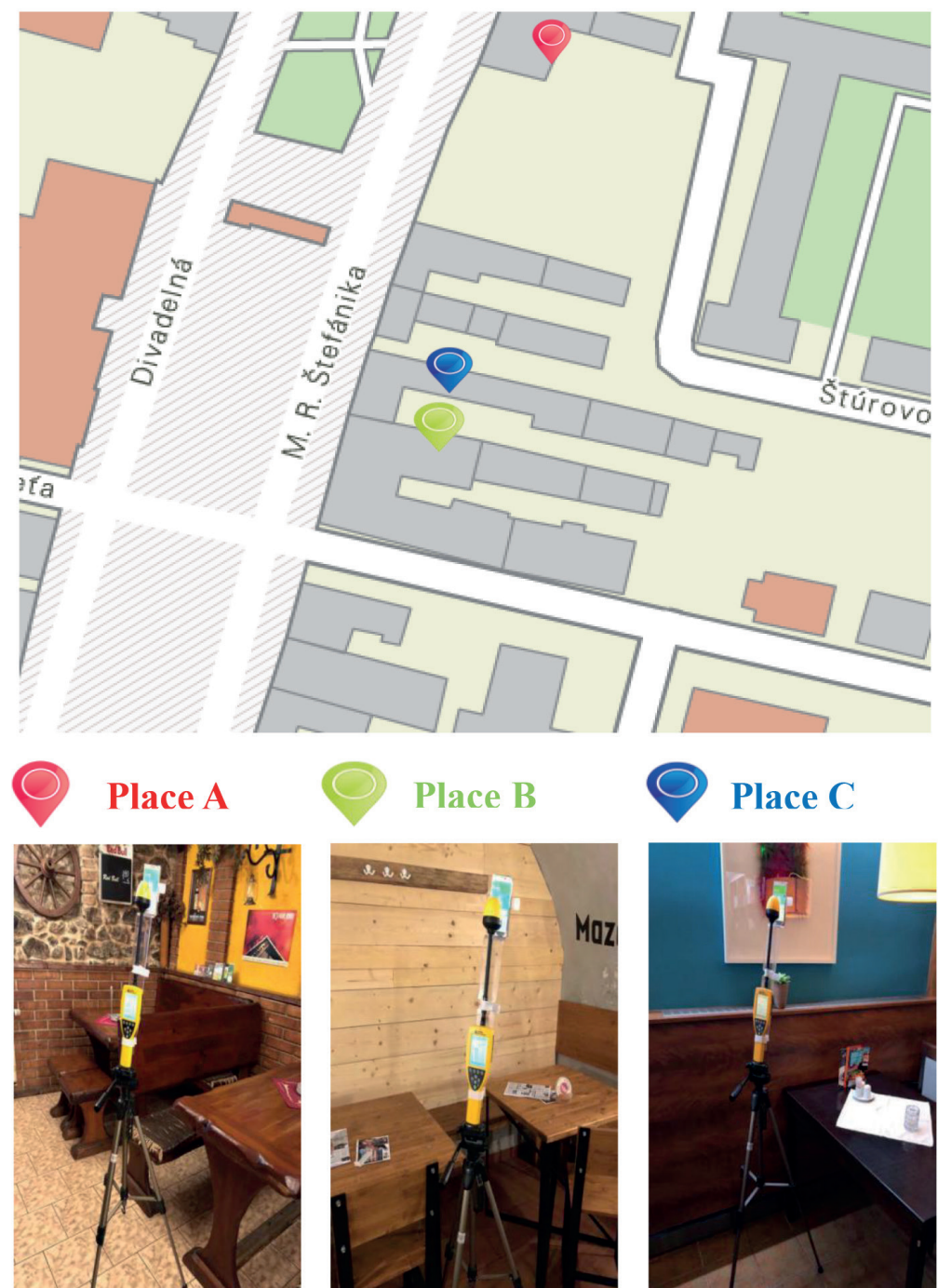

Figure 1 Arrangement of measurement at three places $(A, B, C)$ in city of Martin (see text for detail)

The aim of this study is to determine the changes in $\mathrm{E}$ of RF EMF during data transmission through 3G, 4G and local WiFi networks at different areas of the living environment.

\section{Methods}

The E intensity of EMF emitted by mobile phones was monitored during the data transfer at three different areas in the city of Martin, Slovakia. All measured places were situated at the basement of the buildings near the city center (either in the restaurant or bar; Figure 1). However, each place was covered by the $3 \mathrm{G}$ and $4 \mathrm{G}$ signal at least for $75 \%$, measured by the mobile phone itself. The local WiFi was also available at each place. The measurements were conducted always during the afternoon between 3:00-6:00 PM, from Monday to Friday. The $\mathrm{E}$ of EMF was measured by the broadband EMF meter Narda NBM 550 which enabled to measure E-field within the frequency range from $100 \mathrm{kHz}$ to $3 \mathrm{GHz}$. Two mobile phones were utilized for the measurements, the Samsung
Galaxy 5 as a measured phone and the iPhone 6 as a calling (broadcasting) phone. Both enabled selection between 3G, 4G or WiFi networks for data transmission. The Narda 550 was fixed on a tripod together with the measuring Galaxy 5 phone (Figure 1) by the custom made plastic holder. The distance between the measuring mobile phone and EMF meter was $0.2 \mathrm{~cm}$. This mobile phone was attached at the height of $140 \mathrm{~cm}$, what corresponds to a person sitting on a chair. In addition, the background $\mathrm{E}$ of EMF was measured at each of the measured place. The arrangement of the trial and measured places are shown in Figure 1.

Before the measurement, the broadband EMF meter Narda NBM 550 was self-calibrated. The measured mobile phone (Samsung Galaxy 5) was set up before each measurement, as follows:

- WCDMA (Wide Band Code Division Multiple Accers) the standard for the $3 \mathrm{G}$ network

- $\quad$ LTE (Long Term Evolution) - the standard for the $4 \mathrm{G}$ network

- WiFi - connected to a local Wifi network 
Table 1 Mean values $(x \pm S D)$ for $E$ of EMP (in V/m) for data transfer through $3 G, 4 G$ and WiFi networks at three places (A, B, $C$ ). ${ }^{* *}=p<0.001, * *=p<0.01, *=p<0.05$ (comparison between WiFi and data $3 G, 4 G$ is given above numbers, between data $3 G$ and $4 G$ below numbers at all places the background $E$ was significantly $(p<0.001)$ lower compared to data $3 G, 4 G$ and WiFi)

\begin{tabular}{|c|c|c|c|}
\hline & $\begin{array}{c}\text { Place A } \\
\mathrm{x} \pm \mathrm{SD}[\mathrm{V} / \mathrm{m}]\end{array}$ & $\begin{array}{c}\text { Place B } \\
\mathrm{x} \pm \mathrm{SD}[\mathrm{V} / \mathrm{m}]\end{array}$ & $\begin{array}{c}\text { Place C } \\
\mathrm{x} \pm \mathrm{SD}[\mathrm{V} / \mathrm{m}]\end{array}$ \\
\hline Data 3G & $\begin{array}{c}8.84 \pm 0.79 \text { ** } \\
(\mathrm{n}=10)\end{array}$ & $\begin{array}{c}11.21 \pm 1.16 * \\
(\mathrm{n}=10)\end{array}$ & $\begin{array}{c}5.69 \pm 0.72 \\
(n=10)\end{array}$ \\
\hline Data 4G & $\begin{array}{c}21.06 \pm 1.59 \text { *** } \\
* * * *(\mathrm{n}=10)\end{array}$ & $\begin{array}{c}20.96 \pm 3.05 \text { **** } \\
* *(\mathrm{n}=10)\end{array}$ & $\begin{array}{c}11.85 \pm 2.07 * \\
* *(\mathrm{n}=10)\end{array}$ \\
\hline WiFi & $\begin{array}{c}4.03 \pm 0.29 \\
(n=10)\end{array}$ & $\begin{array}{c}4.23 \pm 0.41 \\
(n=10)\end{array}$ & $\begin{array}{c}3.7 \pm 0.57 \\
(n=10)\end{array}$ \\
\hline Backg. & $\begin{array}{c}0.35 \pm 0.24 \\
(\mathrm{n}=5) * * *\end{array}$ & $\begin{array}{c}0.93 \pm 0.47 \\
(\mathrm{n}=5)^{* * * *}\end{array}$ & $\begin{array}{c}0.26 \pm 0.17 \\
(\mathrm{n}=5)^{* * * *}\end{array}$ \\
\hline
\end{tabular}

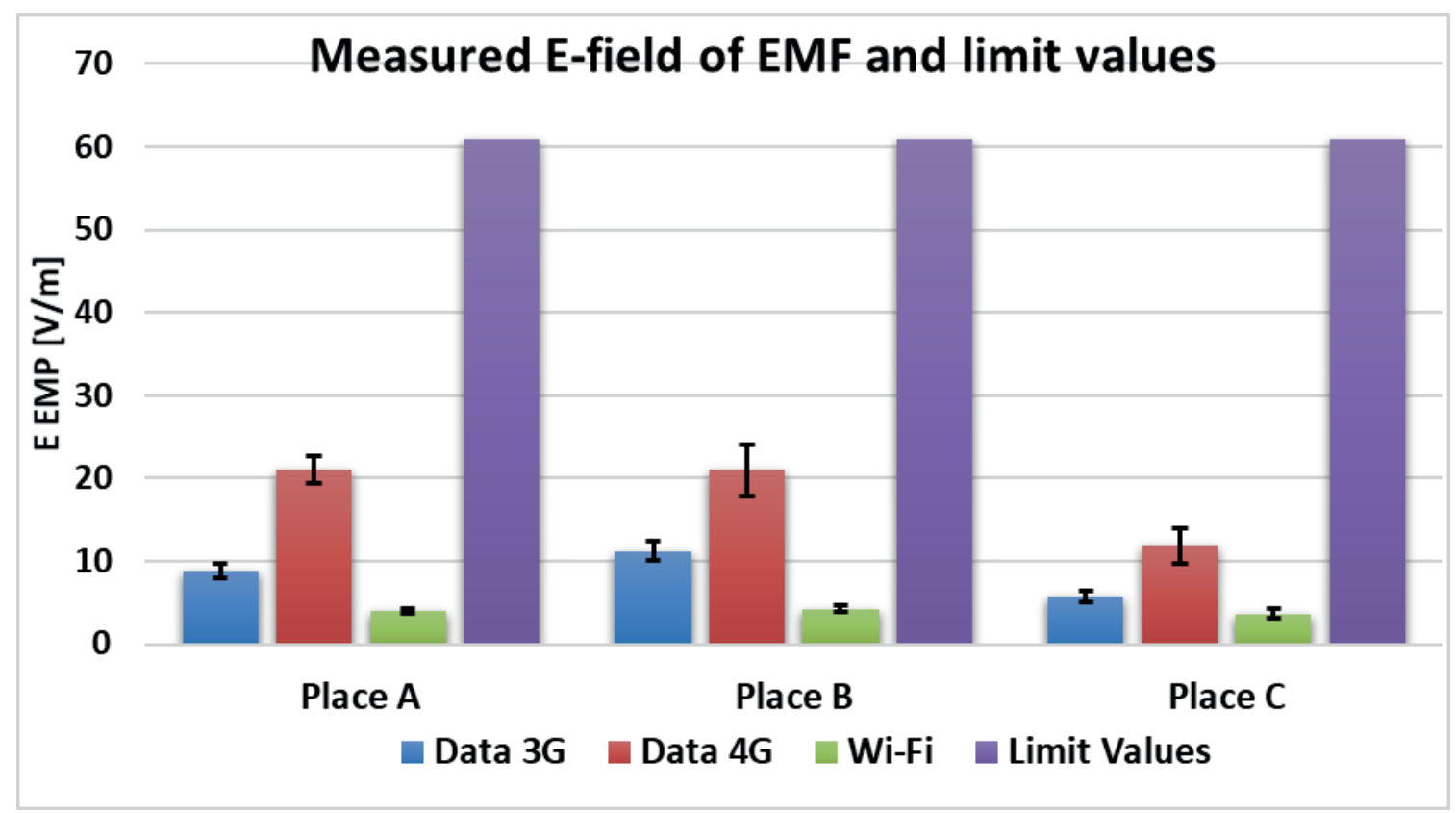

Figure 2 Graphical representation of the mean values of E EMF for tested networks (Data 3G, Data 4G, WiFi) taken at places A, B, C, and the limit values (Limit Values) given by the Decree of Ministry of Health No. 534/2007 C

The application Messenger was utilized for data transmission. It is a software application for cell phones widely used for calling or a video chat. In our study, this application was used to make a call between the cell phones. During the data transmission, the calling phone was distant enoughfrom the measuring phone not to disturb the transmission. The measurement started after the call was answered. The total number of the measurements was 105 of which ten measurements were performed for each place and standard and 5 for background. One measurement lasted 6 minutes and the limit value according to the ICNIRP recommendations was set to $61 \mathrm{~V} / \mathrm{m}$.

For statistical evaluation Microsoft Office Excel and GraphPad InStat 3 was used. These programs allowed to compare the values obtained under three different tested conditions. Data are expressed as mean and standard deviation $(\mathrm{x} \pm \mathrm{SD})$. T-test and ANOVA were used to compare the data between the measured networks.

\section{Results}

The results showed the significant differences between the local WiFi network and the $3 \mathrm{G}$ network at the place $A(p<0.01)$ and B $(p<0.05)$, but not at the place C (Table 1$)$. The significant differences were also found between the local WiFi network and the $4 \mathrm{G}$ network at places A $(\mathrm{p}<0.001), \mathrm{B}$ $(p<0.001)$, and $C(p<0.05)$. Significant differences between the $3 \mathrm{G}$ and the $4 \mathrm{G}$ were identified at place $\mathrm{A}(\mathrm{p}<0.001), \mathrm{B}$ $(p<0.01)$ and $C(p<0.01)$. The background values of $E \mathrm{EMF}$ 
were significantly $(\mathrm{p}<0.001)$ lower at all measured places compared to the values of active data.

As stated before, the limit value for each measured frequency range was $61 \mathrm{~V} / \mathrm{m}$. According to the results, the limit values have not been exceeded at any place (Figure 2).

\section{Discussion}

In this study we evaluated E-field intensity of the EMF during the data transmission through the $3 \mathrm{G}, 4 \mathrm{G}$ and local WiFi networks at selected places of the living environment in the city of Martin. Our results showed that the highest values of $\mathrm{E} \mathrm{EMF}$ were revealed during the data transmission using the $4 \mathrm{G}$ network at all measured places. The $4 \mathrm{G}$ values were approximately twice as much compared to the $3 \mathrm{G}$ and 4 to 5 times higher compared to $\mathrm{WiFi}$. The lowest values were measured during the local WiFi network transmission at the same places. It is interesting, that at the place with minimal background (Place C), the $3 \mathrm{G}, 4 \mathrm{G}$ and WiFi values were also the lowest.

For voice and data transmissions the $3 \mathrm{G}$ uses frequency range $2100 \mathrm{MHz}$ and the $4 \mathrm{G}$ mobile network $2600 \mathrm{MHz}$ or $800 \mathrm{MHz}$ [19-20]. The upcoming network of the fifthgeneration (5G), nowadays intended solely for the data transmission, employs the frequency range around $26 \mathrm{GHz}$ (in Europe) [20]. At this frequency, the wavelength of the EMF wave is approx. $1 \mathrm{~mm}$ representing extremely short waves. The ability of such short waves to cause different types of the resonance effects (frequency windows [21]) is higher for inhomogeneous biological tissues as the human body is. Belyaev [21] proposed that $2 \mathrm{G}$ users during the talk are exposed to microwave radiation at several frequency bands. The base transceiver station (BTS) can change the transmission frequency even during the talk by frequency hopping. The $2 \mathrm{G}$ uses Gaussian Minimum Shift Keying modulation but the 3G employs Quadrature Phase Shift Keying modulation what may explain its higher biological effect. [22] Parameters such as frequency and signal modulation can also significantly affect biological effects caused by mobile phones. It is most likely that an excessive exposure to mobile devices working at $4 \mathrm{G}$ or $5 \mathrm{G}$ networks becomes more dangerous for the biological system.

Study group Misek et al. [23] described the measurement of RF EMF in the living environment. They found that, the distribution of E EMF in the city center was $0.16 \pm 0.02 \mathrm{~V} / \mathrm{m}$ for $3 \mathrm{G}, 0.048 \pm 0.005 \mathrm{~V} / \mathrm{m}$ for $4 \mathrm{G}$ and $9.81 \pm 3.66 * 10^{-3} \mathrm{~V} / \mathrm{m}$ for WiFi. Similar results were revealed by the Hardell group [24], where six places in Stockholm Old Town were investigated for the distribution of $3 \mathrm{G}, 4 \mathrm{G}$ and WiFi networks. However, our results of the background E EMF in the city center was higher in all measured environments even measured in the basements of the buildings. The difference could be given by a different distance from BTS and WiFi transmitters as well as their number resulting in different signal coverage.
In the earlier study of our experimental group [25], the $\mathrm{E}$ of EMF produced by mobile phones was measured at the working environment in the grammar school. These results are in line with the data presented in this study in active mode of the phone (calling, data transmission, messages) and also for the background measurements. However, comparing to our results, we utilized one cell phone only where Spiguthova et al. used several phones in a time with higher distance from the meter.

Paljanos et al. [26] assessed the exposure of mobile phone using $3 \mathrm{G}$ and $4 \mathrm{G}$ networks. In this study, they compare near-field radiated power levels from mobile phone for various data and voice application services. General observations have shown that the higher $3 \mathrm{G}$ values barely reached the $4 \mathrm{G}$ highest measured values. The mobile application "Messenger" did not show higher EMF exposure comparing to the "WhatApp" mobile application. They revealed approximately 2.5 fold higher levels for $4 \mathrm{G}$ network rather than $3 \mathrm{G}$ network. These results are consistent with our results since we observed 2.38 fold higher E-field for the $4 \mathrm{G}$ compared to the $3 \mathrm{G}$ network.

The study presented by Khalid et al. [27] investigated WiFi exposure at schools. They surveyed EMF exposure in the form of WiFi signal from WiFi devices at $0.5 \mathrm{~m}$ distance. They found, that the E EMF from the WiFi device is influenced by the WiFi signal. This study showed lower measured values than our study. However, they placed measuring device $0.5 \mathrm{~m}$ away from the WiFi source, comparing to our study where the broadband meter was placed $0.2 \mathrm{~cm}$ from the WiFi source represented by the mobile phone.

It appears that the limit values for EMF radiation are currently insufficient and outdated, hence they were defined in 1998. For the frequency range from $2 \mathrm{GHz}$ to 300 $\mathrm{GHz}$, the constant limit of $61 \mathrm{~V} / \mathrm{m}$ applies, which is no longer an adequate value. Based on the results of the studies, consideration should be given to reassessing and possibly changing of the existing limit values in relation to a current EMF sources, as well as in relation to proposal of the $5 \mathrm{G}$ networks.

The $\mathrm{E}$ of RF EMF emitted from the mobile devices is influenced by several parameters such as its frequency, character of an environment (shielded or unshielded), SAR value of mobile phone, a distance from the source, modulation, polarization, etc. Nowadays the most of the mobile providers do not admit the possible hazard and serious side effects of the RF EMF on the human and the animal bodies from the cellular phones and the BTSs. Providers are trying to speed up the data transfer selecting between the $3 \mathrm{G}, 4 \mathrm{G}$ and $5 \mathrm{G}$ networks trying to increase the frequency and decrease the E of EMF and the SAR. Thus, the emitted spectrum contains additional frequencies which may oscillate DNA in living cells and thus affect the genetic material of the cells [28].

Therefore, we consider as important to continue with studies of the RF EMF transmissions through the $3 \mathrm{G}, 4 \mathrm{G}$, the local Wifi networks and the future $5 \mathrm{G}$ in the living and the working environments. Proper analyses of detrimental 
effects of the mobile networks on the human body are necessary.

\section{Conclusion}

Our measurements showed a higher level of the $\mathrm{E}$ of EMF generated by a mobile phone during data transmission at the $4 \mathrm{G}$ and $3 \mathrm{G}$ networks compared to a local WiFi network at the underground places. Results proved that safer way of the data transmission is to use the WiFi network. However, the limit values listed in the Decree of the Ministry of Health of the Slovak Republic were not exceeded during the transmission for any of the measured standards.

\section{Acknowledgment}

This study was supported by the Slovak Research and Development Agency under the project APVV-0189- 11 (prof. Jakus).

\section{Reference}

[1] Electromagnetic fields report, Special Eurobarometer 347/Wave 73.3 - ZNS Opinion and Social - European Commission [online]. [Viewed 2019-01-18]. Available from: http://ec.europa.eu/commfrontoffice/publicopinion/archives/ebs/ ebs_347_en.pdf

[2] AZIRA, E., ZOBIDACH, O. S. An acceptance of 4G (fourth generation) mobile network in Malaysia. International Journal of Information and Communication Technology Research [online]. 2013, 3(8), p. 232-237. ISSN 2223-4985. Available from: https://www.academia.edu/37207597/AN_ACCEPTANCE_OF_4G_FOURTH_GENERATION_MOBILE_ NETWORK_IN_MALAYSIA

[3] ANWAR, T. L., LI, L. W. Performance analysis of 3G communication network. ITB Journal of Information and Communication Technology [online]. 2008, 2(2), p. 130-157. ISSN 2338-5499. Available from: http://journals.itb.ac.id/ index.php/jictra/article/view/179

[4] SOOD, R., GARD, A. Digital society from $1 \mathrm{G}$ to 5G: a comparative study. Intermational Journal of Application or Innovation in Engineering \& Management [online]. 2014, 3(2), p. 186-193. ISSN 2319-4847. Available from: https://pdfs.semanticscholar.org/9a4d/f06daea14e6521e24ee1fc3b949f257b7a0f.pdf

[5] BARABAS, J., RADIL, R., MALIKOVA, I. Modification of S. cerevisiae growth dynamics using low frequency electromagnetic fields in the 1-2 khz range. BioMed Research International [online]. 2015, 694713, p. 1-5. ISSN 2314 6133 , eISSN 2314-6141. Available from: http://dx.doi.org/10.1155/2015/694713

[6] BARABAS, J., RADIL, R., JANOUSEK, L. Role of magnetic flux density in LF EMF experiments targeting Ca2+, Na+ and K+ ions. 2018 EMF-Med $1^{\text {st }}$ World Conference on Biomedical Applications of Electromagnetic Fields (EMF-Med) : proceedings. 2018. ISBN 978-953-290-078-8, p. 1-2.

[7] Electromagnetic fields and public heath Intermediate Frequencies (IF) - International EMF Project Information Sheet [online]. [Viewed 2018-12-10]. Available from: https://www.who.int/peh-emf/publications/facts/ intermediatefrequencies_infosheet.pdf

[8] Statement on the "Guidelines for limiting exposure to time-varying electric, magnetic and electromagetic fields (up to $300 \mathrm{GHz}$ )" - ICNIRP [online]. [Viewed 2018-10-12]. Available from: https://www.icnirp.org/cms/upload/publications/ ICNIRPemfgdl.pdf

[9] ROSCH, P. J. Bioelectromegnetic and subtle energy medicine. 2 ed. NY: CRC Press, 2015. ISBN 978-1-14822-3319-3.

[10] Global ICT developments 2018 - ITU Statistics [online]. [Viewed 2018-12-12]. Available from: http://www.itu.int/en/ ITU-D/Statistics/Pages/stat/default.aspx

[11] KIM, J. H., LEE, J.-K., KIM, H.-G., KIM, K.-B., KIM, H. R. Possible effects of radiofrequency electromagnetic field exposure on central nerve system. Biomolecules and Therapeutics [online]. 2019, 27(3), p. 265-275. ISSN 1225-6110. Available from: https://doi.org/10.4062/biomolther.2018.152

[12] MORGAN, L. L., MILLER, A. B., SASCO, A., LEE DAVIS, D. Mobile phone radiation causes brain tumors and should be classified as a probable human carcinogen (2A). International Journal of Oncology [online]. 2015, 46(5), p. $1865-1871$. ISSN 1019-6439. Available from: https://doi.org/10.3892/ijo.2015.2908

[13] MAREGU, N. Long term exposure of mobile phone radiation and human health. Journal of Information Engineering and Applications [online]. 2016, 6(8), p. 22-30. ISSN 2225-0506, eISSN 2225-0506. Available from: https://iiste.org/ Journals/index.php/JIEA/article/download/3227\%/33166

[14] ABESHU, M. A., GELETA, B. Physical health hazards of mobile phone use. Health Care: Current Reviews [online]. 2015, 3(2), p. 1-2. ISSN 2375-4273. Available from: http://dx.doi.org/10.4172/2375-4273.1000153

[15] WANG, D., LI, B., LIU, Y., MA, Y. F., CHEN, S. Q., SUN, H. J., DONG, J., MA, X. H., ZHOU, J., WANG, X. H. Impact of mobile phone radiation on the quality and DNA methylation of human sperm in vitro (in Chinese). National Journal of Andrology [online]. 2015, 21(6), p. 515-520 ISSN 1009-3591. Available from: https://www.ncbi.nlm.nih.gov/pubmed/26242041 
[16] KUCER, N., PAMUKCU, T., Self-reported symptoms associated with exposure to electromagnetic fields: a questionnaire study. Electromagnetic Biology and Medicine [online]. 2013, 33(1), p. 15-17. ISSN 1236-8386. Available from: https://doi.org/10.3109/15368378.2013.783847

[17] What are the health risks associated with mobile phones and their base stations? - WHO [online]. [Viewed 2018-10-10]. Available from: https://www.who.int/features/qa/30/en/

[18] LINHARES, A., SOARES, A., TERADA, M. Determination of measurement points in urban environments for assessement of maximum exposure to EMF associated with a base station. International Journal of Antennas and Propagation [online]. 2014, 297082, p. 1-7. ISSN 1687-5869, eISSN 1687-5877. Available from: http://dx.doi.org/10.1155/2014/297082

[19] WIESER V. Mobilne radiove siete II. Adaptacia technickych a systemovych parametrov / Mobile radio networks II. Adaptation of technical and system parameters (in Slovak). Zilina: EDIS, 2004. ISBN 80-8070-345-0.

[20] Radio spectrum policy group strategic spectrum roadmap towards 5G for Europe, Second Opinion on 5G networks - European Commission [online]. [Viewed 2018-09-12]. Available from: https://circabc.europa.eu/sd/a/fe1a3338-b75143e3-9ed8-a5632f051d1f/RSPG18-005final-2nd_opinion_on_5G.pdf

[21] BELYAEV I. Non-thermal biological effects of microwaves. Microwaves Review [online]. 2005, 11(2), p. 13-29. ISSN 1450-5835. Available from: https://doi.org/10.1080/15368370500381844

[22] Belyaev, I., DEAN, A., EGER, H., HUBMANN, G., JANDRISOVITS, R., KERN, M., KUNDI, M., MOSHAMMER,

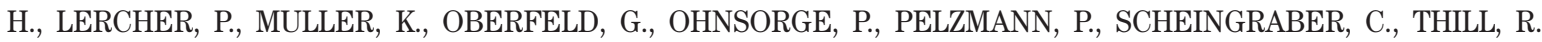
European EMF guideline 2016 for the prevention, diagnosis and treatment of EMF - related health problems and illnesses. Reviews on Environmental Health [online]. 2016, 31(3), p. 363-397. ISSN 2191-0308. Available from: https://doi.org/10.1515/reveh-2016-0011

[23] MISEK, J., LAUKOVA, T., KOHAN, M., VETERNIK, M., JAKUSOVA, V., JAKUS, J. Measurement of low-level radiofrequency electromagnetic fields in the human environment. Acta Medica Martiniana [online]. 2018, 18(2), p. 27-33. ISSN 1335-8421. Available from: https://doi.org/10.2478/acm-2018-0010

[24] HARDELL, L., CARLBERG, M., KOPPEL, T., HEDENDAHL, L. High radiofrequency radiation at Stockholm Old Town: An exposimeter study including the Royal Caste, Supreme Court, three major squares and the Swedish Parliament. Molecular and Clinical Oncology [online]. 2017, 6(4), p. 462-476. ISSN 2049-9469, eISSN 2049-9469. Available from: https://doi.org/10.3892/mco.2017.1180

[25] SPIGUTHOVA, D., HABINAKOVA, H., MISEK, J., JAKUSOVA, V., JAKUS, J. Meranie parametrov elektromagnetickych poli pri pouzivani prostriedkov mobilnej komunikacie v skolskom prostredi / Measurement of electromagnetic fields using mobile communication in school environment (in Slovak). Lekar a technika [online]. 2015, 45(4), p. 122-128. ISSN 2336-5552, eISSN 2336-5552. Available from: https://ojs.cvut.cz/ojs/index.php/CTJ/article/view/4260

[26] PALJANOS, A., MICLAUS, S., BEChET, P., MUNTEANU, C. Assessment of mobile phone user exposure to UMTS and LTE signals: comparative near-field radiated power levels for various data and voice application services. Journal of Electromagnetic Waves and Applications [Online]. 2016, 30(9), p. 1-15. ISSN 1569-3937. Available from: https://doi.org/10.1080/09205071.2016.1167634

[27] KHALID, M., MEE, T., PEYMAN, A., ADDISON, D., CALDERON, C., MASLANYJ, M., MANN, S. Exposure to radio frequency electromagnetic fields from wireless computer networks: duty factors of Wi-Fi devices operating in schools. Progress in Biophysics and Molecular Biology [online]. 2011, 107(3), p. 412-420. ISSN 0079-6107, eISSN $1873-1732$. Available from: https://doi.org/10.1016/j.pbiomolbio.2011.08.004

[28] MARKOV, M. Mobile communications and public health. NY: CRC Press, 2018. ISBN 978-0-203-70510-0. 